\title{
INTEGRASI QANUN SYARIAT ISLAM KE DALAM PEMBELAJARAN PENDIDIKAN AGAMA ISLAM
}

\author{
AGUS SALIM \\ Pengawas Madrasah Kankemenag Kabupaten Aceh Selatan \\ e-mail: agussawang@gmail.com
}

\begin{abstract}
ABSTRAK
Mata pelajaran Pendidikan Agama Islam merupakan salah satu mata pelajaran yang telah ditetapkan dalam kurikulum nasional, sehingga semua konten yang terkandung di dalamnya merupakan bahagian yang tidak terpisahkan dari peraturan pemerintah pusat yang kemudian diberlakukan kepada sekolah-sekolah umum di Indonesia. Di sisi lain Aceh memiliki keistimewaan yang diamanahkan oleh Undang-Undang Nomor 11 Tahun 2006 Tentang Pemerintahan Aceh. Keistimewaan tersebut adalah pelaksanaan syariat Islam yang secara umum di atur dalam Qanun Nomor 8 Tahun 2014 Tentang Pokok-Pokok Syariat Islam. Pelaksanaan syariat Islam merupakan tanggungjawab pemerintah Aceh baik di tingkat Provinsi maupun Kabupaten/Kota. Oleh karenanya menarik untuk melihat bagaimana integrasi yang dapat dilakukan guna mewujudkan pelaksanaan syariat Islam hingga ke tingkat sekolah, salah satu yang dapat dilakukan adalah dengan memanfaatkan mata pelajaran Pendidikan Agama Islam. Penelitian ini adalah penelitian kualitatif dengan metode pengumpulan data melalui wawancara, observasi dan dokumentasi. Penelitian ini dilakukan di SMAN 1 Tapaktuan Aceh Selatan. Hasil penelitian ini menunjukkan bahwa integrasi pokok-pokok syariat Islam telah dilaksanakan pada saat proses pembelajaran. Proses pembelajaran di kelas berlangsung dengan mentransformasikan pokok-pokok syariat Islam menjadi bagian dari materi yang disampaikan. Penelitian ini menunjukkan bahwa integrasi antara pokok-pokok syariat Islam dapat dilakukan dengan memanfaatkan proses pembelajaran di kelas dengan memasukkan materi pokok-pokok syariat Islam ke dalam RPP, hanya saja tidak semua pokok-pokok syariat Islam dapat diintegrasikan dengan RPP guru.
\end{abstract}

Kata Kunci: Integrasi, Pokok-Pokok Syariat Islam, Pembelajaran Pendidikan Agama Islam

\section{PENDAHULUAN}

Secara harfiah integrasi berlawanan dengan perpisahan, suatu sikap yang meletakkan tiap-tiap bidang dalam kotak-kotak yang berlainan (Zainal Abiding Bagir, 2010) sehingga integrasi dapat juga di tafsirkan sebagai upaya untuk menyatukan hal-hal yang berbeda dala satu kesatuan yang sama. Integrasi memiliki sinonim dengan perpaduan, penyatuan, atau penggabungan, dari dua objek atau lebih. Sebagaimana dikemukakan oleh poerwandarminta, yang dikutip Trianto, bahwa integrasi adalah penyatuan supaya menjadi satu atau kebulatan yang utuh (Trianto, 2007).

Mata pelajaran Pendidikan Agama Islam merupakan salah satu mata pelajaran yang telah ditetapkan dalam kurikulum nasional, sehingga semua konten yang terkandung di dalamnya merupakan bahagian yang tidak terpisahkan dari peraturan pemerintah pusat yang kemudian diberlakukan kepada sekolah-sekolah umum di Indonesia. Di sisi lain Aceh memiliki keistimewaan yang diamanahkan oleh Undang-Undang Nomor 11 Tahun 2006 Tentang Pemerintahan Aceh. Keistimewaan tersebut adalah pelaksanaan syariat Islam yang secara umum di atur dalam Qanun Nomor 8 Tahun 2014 Tentang Pokok-Pokok Syariat Islam.

Proses belajar mengajar tidak hanya dibatasi pada kurikulum saja, akan tetapi juga ada bahagian yang disebut dengan pembelajaran. Proses pembelajaran merupakan bahagian interaksi langsung antara guru dengan siswa di kelas. Dalam Qanun Nomor 5 Tahun 2008 memberikan arti bahwa pembelajaran merupakan proses interaksi peserta didik dengan pendidik dan sumber belajar pada suatu lingkungan belajar (Qanun No.5, 2008).

Pembelajaran merupakan inti dari proses belajar dan mengajar yakni dimana proses yang mengajarkan baik guru maupun siswa dalam mengatur, mengelola lingkungan yang 
tampak disekitar yang bertujuan untuk membangkitkan semangat belajar peserta didik. Hal ini tentunya menuntut para guru untuk dapat menjadi solusi kepada peserta didik yang bermasalah (Aprida Pane, M. Darwis Dasapong, 2007). Sehingga dikatakan pembelajaran merupakan pola pengaturan karena guru menjadi bagian terpenting dalam proses belajar mengajar, sehingga guru dituntut untuk mengatur lingkungan sekitar makanya dikatakan hakikat dari pembelajaran adalah pengaturan (Askhobul Kiram, 2007).

Pembelajaran merupakan hal yang paling penting sehingga materi muatan atau materi isi yang disampaikan oleh guru harus mampu diserap dan dipahami oleh para peserta didik. Pengertian pembelajaran menurut ketentuan Undang-Undang RI No. 20 Tahun 2003 tentang Sistem Pendidikan Nasional menyebutkan bahwa pembelajaran adalah proses interaksi peserta didik dengan pendidik dan sumber belajar pada suatu lingkungan belajar (UU No. 20, 2003).

Pembelajaran tidak hanya mengatur para peserta didik, akan tetapi lebih mendidik para siswa untuk bersikap lebih dewasa. Pengertian sederhana sebelumnya ini memberikan pemahaman bahwa pembelajaran yang berlangsung tidak hanya terbatas pada memindahkan pengetahuan dari guru ke peserta didik atau transfer materi akan tetapi guru juga harus terlibat menyampaikan nilai-nilai agar para siswa lebih dewasa dalam memahami sesuatu (Sugiharto, 2007).

Apabila melihat definisi dari pembelajaran tersebut dan kemudian dibandingkan dengan apa yang terjadi dilapangan atau di kelas maka sangat menarik untuk dikaji lebih dalam khususnya Sekolah Manengah Atas yang ada di provinsi Aceh. Aceh sebagai daerah istimewa di Indonesia memiliki aturan tersendiri dalam hal pengelolaan daerahnya, tidak terkecuali dalam bidang penyelenggaraan pendidikan di Aceh.

Penyelengaaraan pendidikan di Aceh di atur dalam Qanun Nomor 5 Tahun 2008 Tentang penyelenggaraan pendidikan. Tegas dan jelas qanun ini menyebutkan bahwa pendidikan di Aceh untuk mewujudkan tujuan pendidikan nasional. Pada Pasal 4 huruf (a) disebutkan bahwa Penyelenggaraan Pendidikan di Aceh bertujuan mengembangkan seluruh potensi peserta didik menjadi manusia yang salah satunya adalah manusia yang bertakwa kepada Allah SWT.

Pelaksanaan syariat Islam merupakan tanggungjawab pemerintah Aceh baik di tingkat Provinsi maupun Kabupaten/Kota. Oleh karenanya menarik untuk melihat bagaimana integrasi yang dapat dilakukan guna mewujudkan pelaksanaan syariat Islam hingga ke tingkat sekolah, salah satu yang dapat dilakukan adalah dengan memanfaatkan Pembelajaran Pendidikan Agama Islam.

\section{METODE PENELITIAN}

Penelitian ini merupakan penelitian kualitatif. Pemilihan terhadap jenis penelitian ini adalah untuk melihat pemahaman guru mengenai syariat Islam di Aceh. Melihat pemahaman tidak hanya bisa dirasakan melalui obeservasi saja atau teks yang dapat dilihat dan dibaca, akan tetapi juga konteks atau muatan serta subtansi dari teks tersebut. Karena penelitian ini dilakukan di Sekolah Menengah Atas maka melihat pemahaman guru juga dibatasi pada mata pelajaran Pendidikan Agama Islam.

Penelitian kualitatif digunakan oleh peneliti dalam mendekati-memahami, menggali, mengungkap fenomena tertentu dari responden penelitiannya. Adapun yang akan digali disini adalah makna-makna yang dapat dilihat dari sebuah kondisi tertentu yang berasal dari sumber responden. Sejak awal, peneliti harus mampu menentukan metode yang akan digunakan (metode idealnya bersifat tetap, teknik yang bersifat situasional atau fleksibel). Guna meneliti sebuah fenomena yang sampai dengan sekarang belum banyak diketahui/belum terbukti secara ilmiah. 


\section{HASIL DAN PEMBAHASAN}

\section{Hasil}

Hasil penelitian ini menunjukkan bahwa integrasi pokok-pokok syariat Islam telah dilaksanakan pada saat proses pembelajaran. Proses pembelajaran di kelas berlangsung dengan mentransformasikan pokok-pokok syariat Islam menjadi bagian dari materi yang disampaikan. Penelitian ini menunjukkan bahwasanya integrasi antara pokok-pokok syariat Islam dapat dilakukan dengan memanfaatkan proses pembelajaran di kelas dengan memasukkan materi pokok-pokok syariat Islam ke dalam RPP, hanya saja tidak semua pokok-pokok syariat Islam dapat diintegrasikan dengan RPP guru.

\section{Pembahasan}

Integrasi merupakan sebuah teori yang bertujuan untuk menggabungkan beberapa hal yang berbeda, tujuannya adalah untuk melahirkan atau membuat sesuatu yang baru. Aspekaspek pada integrasi sangat penting untuk mendapatkan hal-hal yang sifatnya penggabungan dua hal yang berbeda. Pada bagian ini merupakan penggabungan antara peraturan daerah yaitu Qanun Pokok-pokok Syariat Islam ke dalam pembelajaran Pendidikan Agama Islam.

Qanun Pokok-pokok Syariat Islam merupakan sebuah regulasi lokal atau peraturan daerah yang dibentuk oleh Dewan Perwakilan Rakyat Aceh dan di sepakati dengan gubernur Aceh. Qanun ini merupakan qanun yang diatur dan dibentuk untuk melanjutkan amanah yang ada pada Undang-Undang Nomor 11 Tahun 2006 Tentang Pemerintahan Aceh.

Jika dibaca sekilas pada qanun pokok syariat Islam, maka yang tekstual adalah pengaturan secara umum mengenai pokok-pokok syariat Islam di Aceh. Hal ini menandakan bahwa qanun ini tidak mengatur lebih detail hal-hal yang berkaitan dengan pelaksnaan syariat Islam.

Qanun Pokok-pokok Syariat Islam ini juga mengatur mengenai tarbiyah (pendidikan), artinya pendidikan juga menjadi bagian dari proses pelaksanaan syariat Islam di Aceh. Pendidikan menjadi penting untuk memperkuat akar pelaksanaan syariat Islam di Aceh, sehingga peran pendidikan baik itu pendidikan dasar hingga ke pendidikan tinggi harus ikut peran serta aktif, yang disesuaikan dengan batasan-batasan pada tiap jenjang pendidikan tersebut, sehinga dapat disimpulkan bahwa qanun pokok-pokok syariat Islam merupakan qanun yang mengatur cakupan-cakupan yang berhubungan dengan pelaksnaan syariat Islam, yaitu mengatur hal-hal umum.

Disisi lain ada pendidikan formal yaitu Sekolah Menengah Atas Negeri atau Madrasah Aliyah Negeri yang menjadi bagian tidak terpisahkan dari sistem pemerintahan di Aceh. Di sinilah peran pendidikan sebagai sarana dalam hal memperkuat pilar-pilar syariat Islam di Aceh, hanya saja pola pengintegrasian tersebut yang benar-benar kuat pada ranah proses transaksi pengetahuan di kelas.

Proses transaksi pendidikan tersebut dilakukan pada saat proses belajar mengajar di kelas, ada komunikasi dua sisi antara guru dengan peserta didik di kelas. Hal ini adalah peluang proses memperkuat pilar-pilar pelaksanaan syariat Islam di Aceh.

Bahagian pembelajaran ini tenaga pendidik atau guru memiliki peran penting, karena para tenaga pendidik merupakan orang-orang yang terpilih dan orang-orang yang profesional dibidanngya, khususnya guru yang mengajar di bidang mata pelajaran Pendidikan Agama Islam.

Pada saat melaksanakan proses pembelajaran di kelas, maka tenaga pendidik memberikan materi yang telah disediakan berdasarkan kurikulum. Kurikulum merupakan bahan ajar yang telah ditetapkan secara baku oleh pemerintah. Demikian juga hal nya dengan kurikulum mata pelajaran Pendidikan Agama Islam.

Materi kurikulum yang berdasarkan ketentuan pemerintah maka sudah seharusnya dibutuhkan kreatifitas tenaga pendidik untuk dikembangkan agar bermuatan cakupan-cakupan pelaksanaan syariat Islam di Aceh. Kreatifitas tersebut adalah untuk mengintegrasikan dengan 
nilai-nilai syariat Islam. Hal ini yang dijelaskan oleh guru Pendidikan Agama Islam di sekolah tersebut seperti yang peneliti terima dari Zulmadewi.

Wawancara peneliti dengan Zulmadewi (2021) menjelaskan bahwa untuk mewujudkan perpaduan antara qanun pokok-pokok syariat Islam dalam mata pelajaran Pendidikan Agama Islam diperlukan kreatifitas guru.

Penyampaian mengenai pokok-pokok syariat Islam di dalam proses pembelajaran di kelas merupakan dorongan moral, hal ini menjadi amanah yang harus disampaikan kepada siswa. terutama mata pelajaran yang diampu adalah Pendidikan Agama Islam, sehingga dorongan moral tersebut semakin kuat untuk disampaikan kepada siswa ketika berlangsungnya proses pembelajaran.

Selanjutnya Zulmadewi menegaskan bahwa Kenapa harus ada kreatifitas? Karena para guru mata pelajaran Pendidikan Agama Islam sudah pernah mengikuti pelatihan yang dilaksanakan oleh pemerintah Aceh.

Para guru yang mengajarkan mata pelajaran Pendidikan Agama Islam pernah mengikuti pelatihan yang diselenggarakan oleh pemerintahan Aceh di Banda Aceh, karena pelatihan tersebut makanya amanah serta beban moral sebagai pengajar mata pelajaran Pendidikan Agama Islam semakin menguat untuk menyampaikan materi-materi yang berkaitan dengan syariat Islam di Aceh.

Zulmadewi kembali menjelaskan bahwa sebelumnya kami tidak tahu adanya pendidikan yang berhubungan dengan syariat Islam, setelah mengikuti pelatihan baru kami menyadari bahwa pendidikan merupakan bagian dari upaya pelaksanaan syariat Islam, karena saya guru mata pelajaran Pendidikan Agama Islam, barang kali ini kesempatan saya untuk menyampaiakan apa yang saya tahu tentang syariat Islam di Aceh, tetapi tidak semua, hanya apa-apa yang saya anggap berkaitan dengan mata pelajaran Pendidikan Agama Islam.

Sebelum adanya pelatihan yang diadakan oleh Pemerintahan Aceh kepada para guru Pendidikan Agama Islam mengenai pelaksanaan syariat Islam, secara pribadi menegaskan bahwasanya dia tidak tahu mengenai adanya qanun pokok syariat Islam khususnya mengenai bidang Tarbiyah (pendidikan).

Selanjutnya Zulmadewi menjelaskan:

Walaupun di Aceh ada pengaturan tentang pelaksanaan syariat Islam, dan diharapakan juga sampai ke tingkat sekolah, kami selaku guru tetap menggunakan kurikulum yang ada, karena kurikulum Pendidikan Agama Islam sudah ditetapkan pemerintah.

Bahwa materi ajar mata pelajaran Pendidikan Agama Islam di Sekolah Menengah Atas Negeri 1 Tapaktuan masih berasal dari pemerintahan pusat yakni masih berstandar nasional sehingga menjadi bagian terpisah dari pokok-pokok syariat Islam di Aceh karena hal ini merupakan materi lokal di Aceh saja, artinya dua hal ini merupakan sesuatu yang berbeda. Zulmadewi menegaskan :

Guna mewujudkan pelaksanaan syariat Islam dibutuhkan kreatifitas guru pada saat berlangsungnya proses pembelajaran. Sehingga yang dapat dimanfaatkan untuk mewujudkan transformasi pengetahun tersebut adalah dengan metode ceramah, diskusi dan demonstrasi materi ajar.

Berkaitan dengan rasa ingin tahu para peserta didik terhadap materi-materi yang berkaitan dengan pokok-pokok syariat Islam di Aceh mereka sangat antusias sekali, karena hal ini tidak mereka temukan di buku ajar, hal ini peneliti ketahui ketika melakukan wawancara dengan Zulmadewi:

Kreatifitas dalam menyatukan dua perbedaan tersebut masih terbatas, karena masih mengikuti kurikulum nasional. Kemudian tidak ada materi pada qanun pokok tersebut bisa digunakan pada materi ajar mata pelajaran Pendidikan Agama Islam.

Materi pokok-pokok syariat Islam ini tidak memiliki jam yang banyak untuk di bahas, bahkan materi ini hanya disampaikan sekilas saja, dan materi yang disampaikan juga harus dipilah-pilah karena tidak semua bisa disampaikan dan harus disesuaikan dengan aturan 
nasional dan tidak boleh bertentangan dengan Pancasila dan Undang-undang Dasar 1945, oleh karena itu ada hal-hal yang bisa diintegrasikan serta keterkaitan antara pelajaran Pendidikan Agama Islam dengan pokok-pokok syariat Islam di Aceh.

Observasi yang peneliti lakukan terhadap guru mata pelajaran Pendidikan Agama Islam juga mengajarkan materi-materi yang diatur dalam Qanun pokok-pokok syariat Islam secara umum, peneliti memperhatikan bahwa materi yang dikaitkan dengan pokok-pokok syariat Islam lebih kepada butir-butir yang di atur pada materi ibadah, tarbiyah, wajib berprilaku dengan tuntunan Islam, menghormati dan menegakkan nilai-nilai kemanusian, budaya pergaulan hidup dan tata busana yang Islami dan bahaya dekadensi moral di era global.

Senada dengan Zulmadewi, Ida Irhami (2021) menuturkan bahwa pernah mengikuti pelatihan yang diselenggarakan oleh Pemerintah Aceh, dan ini merupakan upaya yang bagus untuk melaksanakan syariat Islam di Aceh, dan hal ini kalau bisa tidak berhenti sampai disitu saja.

Pelatihan yang pernah dilaksanakan oleh pemerintah Aceh dalam hal ini adalah Dinas Pendidikan Aceh bisa dikatakan belum terlambat, seharusnya pelatihan tersebut tidak sekali saja. Ida Irhami menjelaskan bahwa sudah seharusnya memanfaatkan pelajaran Pendidikan Agama Islam sebagai media untuk transformasi syariat Islam di Aceh.

Ida Irhami menyebutkan:

Tidak ada pengaturan materi yang dikaitkan dengan syariat Islam di Aceh, yang dibutuhkan adalah upaya guru agar materi tersebut tersampaikan kepada peserta didik. Justru disinilah beban moral para guru Pendidikan Agama Islam di Aceh, sehingga harus ada kreatifias agar terwujudnya keselarasan antara kurikulum Pendidikan Agama Islam dengan pokok-pokok syariat Islam di Aceh..

Ida Irhami merupakan guru Pendidikan Agama Islam yang memiliki gelar Master kemudian menjelaskan Walaupun demikian, ada beberapa hal yang disatukan dari perbedaan tersebut, seperti materi Ibadah, tarbiyah dan akhlak adalah contoh yang merupakan upaya guru untuk menyampaikan kepada peserta didik.

Bahwa terdapat keselarasan dari kedua hal yang berbeda tersebut yakni kurikulum pendidikan agama Islam dengan pokok-pokok syariat Islam. Hanya saja perbedaanya adalah bahwa ada materi dari pemerintahan pusat dan ada materi dari kearifan lokal yang ada di Aceh. Sebenarnya titik temunya adalah terletak pada konten yaitu sama-sama menyampaikan materi keislaman. Kesamaan ini yang dimanfaatkan sebagai materi yang terintegrasi dari keduanya, serta proses pembelajaran merupakan media yang dapat dimanfaatkan sebagai proses integrasi.

Menurut Ida Irhami:

Upaya yang dapat dilakukan agar menyatu dari dua hal yang berbeda ini adalah pada saat berlangsung proses pembelajaran di kelas, guru dibutuhkan kreatifitas karena materi ajar yang berhubungan dengan pelaksanaan syariat Islam di Aceh tidak ada pada kurikulum PAI.

Pemanfaatan proses pembelajaran di kelas guna menyampaikan pokok-pokok syariat Islam dengan waktu yang sangat terbatas serta materi yang terbatas juga mampu memberikan motivasi serta meningkatkan antusias para peserta didik, artinya dibutuhkan kreatifitas para guru pendidikan agama Islam dalam menyusun Rencana Pelaksanaan Pembelajaran (RPP) sebagai bahan yang akan di ajarkan di kelas.

Sebelum wawancara selesai Ida Irhami menjelaskan bahwa:

Pemahaman mengenai syariat Islam telah pernah disosialisasikan, bahkan guru juga pernah mengikuti pelatihan. Namun demikian tidak semua materi yang diatur dalam pokok-pokok syariat Islam dapat diintegrasikan kedalam pembelajaran di kelas, karena walau bagaimanapun kurikulum Pendidikan Agama Islam tetap tunduk kepada kurikulum nasional.

Jika membaca hasil wawancara di atas, maka dibutuhkan kreatifitas para guru untuk mem-breakdown atau turunan dari kurikulum mata pelajaran pendidikan agama Islam ke dalam Rencana Pelaksanaan Pembelajaran (RPP), karena RPP merupakan Rencana Pelaksanaan 
Pembelajaran yang menggambarkan proses pembelajaran serta pengorgaisasian dalam mencapai Kompetensi Dasar.

Dalam pedoman umum pembelajaran untuk penerapan Kurikulum 2013 disebutkan bahwa Rencana Pelaksanaan Pembelajaran (RPP) adalah rencana pembelajaran yang dikembangkan secara rinci dari suatu materi pokok atau tema tertentu yang mengacu pada Silabus. RPP mencakup: (1) data sekolah, matapelajaran, dan kelas/semester; (2) materi pokok; (3) alokasi waktu; (4) tujuan pembelajaran, KD dan indikator pencapaian kompetensi; (5) materi pembelajaran; metode pembelajaran; (6) media, alat dan sumber belajar; (6) langkahlangkah kegiatan pembelajaran; dan (7) penilaian.

Melihat pengertian dari penjelasan di atas maka peluang untuk mengintegrasikan qanun pokok-pokok syariat Islam dengan proses pembelajaran di kelas sangat mungkin di lakukan. Hal ini dapat digambarkan dalam figura sederhana di bawah ini:

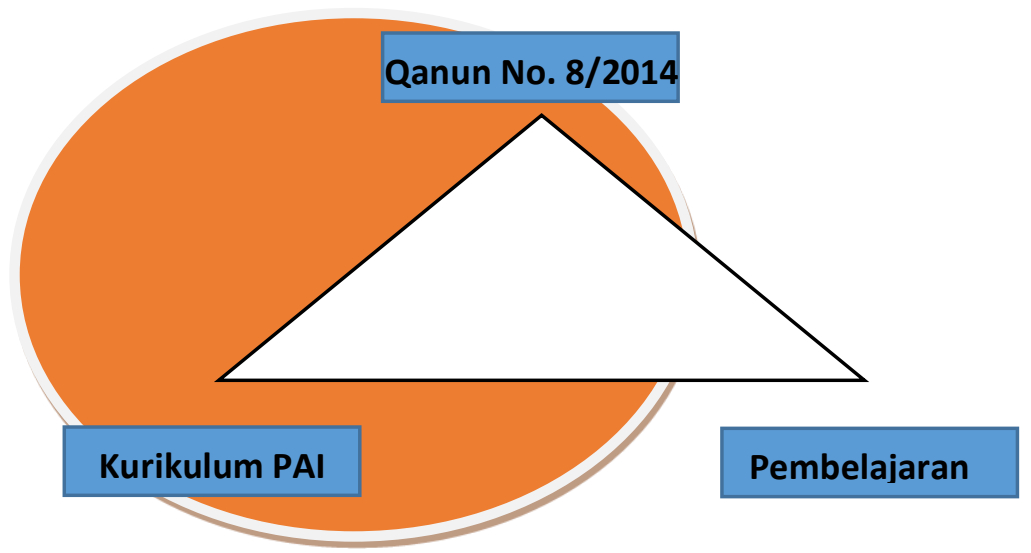

Gambar 1. Pola/Skema pengintegrasian dalam penelitian ini

Gambar di atas menjelaskan bahwa penelitian ini ada mengintegrasikan cakupancakupan yang ada pada Qanun Nomor 8 Tahun 2014 Tentang Pokok-Pokok Syari'at Islam. Setelah melakukan proses pengintegrasian maka ditemukan peluang-peluang serta kecocokan guna mendapatkan pola baru yang selanjutnya akan dilaksanakan dalam proses pembelajaran.

Guna mendapatkan data yang mampu dan dapat diintegrasikan dengan mata pelajaran Pendidikan Agama Islam maka terlebih dahulu yang harus dilakukan oleh peneliti untuk menjawab pembahasan ini adalah dengan melihat cakupan-cakupan yang ada pada qanun pokok-pokok syariat Islam yang di atur dalam Qanun Nomor 8 Tahun 2014 Tentang PokokPokok Syariat Islam. Hal ini dapat digambarkan dalam figura berikut ini:

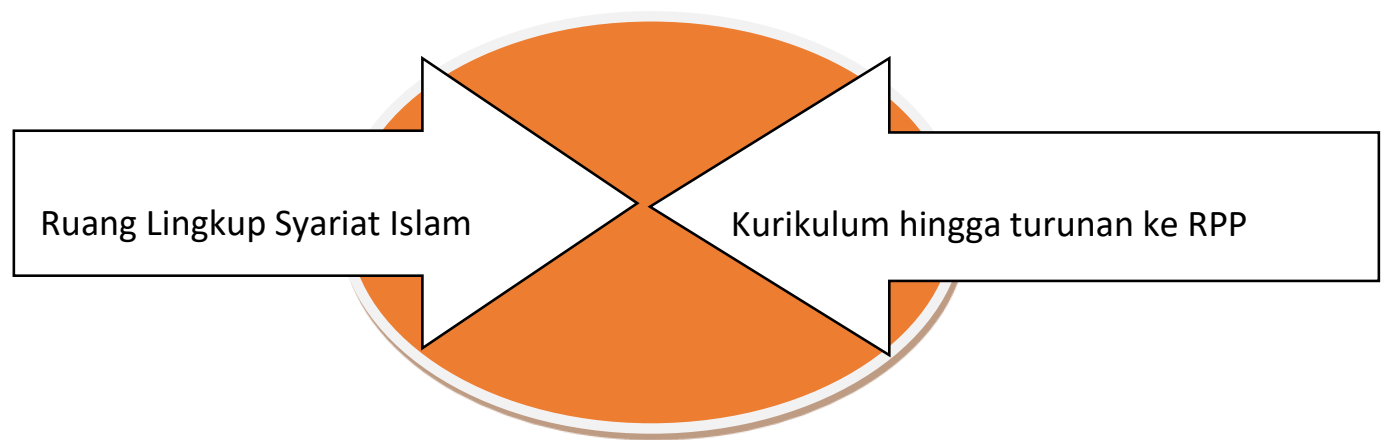

Gambar 2. Figura integrasi qanun dalam penelitian ini

Penjelasan figura di atas bahwa alur ruang lingkup syariat Islam dengan alur kurikulum hingga turunan ke RPP dipadukan dan dicari titik temu dalam lingkaran yang berwarna orange, sampai tahap ini maka fungsi teori integrasi mulai berkerja. Setelah melakukan pembauran peneliti menemukan integrasi yang bisa dilakukan dalam proses pembelajaran di kelas dengan qanun pokok-pokok syariat Islam. 
Ada beberapa titik temu yang bisa di padukan dari dua hal yang berbeda yaitu antara Qanun Nomor 8 Tahun 2014 Tentang Pokok-Pokok Syariat Islam dengan Pembelajaran di kelas, yaitu:

1. Pengaturan mengenai Aqidah merupakan bahagian penting dalam pelaksanaan syariat Islam di Aceh. Namun demikian apabila pengaturan mengenai aqidah ini tidak ditafsirkan ke dalam bentuk kurikulum di sekolah yang kemudian jabarkan sebagai bentuk turunan dari pembelajaran maka pengaturan mengenai aqidah ini akan mengawang-nganwang, aritnya tidak membumi. Salah satu cara yang bisa dilakukan adalah mengintegrasikan dalam pembelajaran sebagai bagian dari transformasi pengetahuan di kelas, tentunya materi ini tidak bisa dilepaskan dari kurikulum. Sehingga dibutuhkan penyesuaian dengan kurikulum. Penyesuaian ini membutuhkan krativitas dari guru yang mengajar mata pelajaran Pendidikan Agama Islam.

2. Pengaturan mengenai syariah adalah tuntunan dan aturan hukum Islam dalam semua aspek kehidupan. Artinya pengaturan mengenai syariah ini tidak bisa ditafsirkan secara kaku, akan tetapi harus holistic dan menyeluruh termasuk di dalamnya semua sendi kehidupan dalam hal ini adalah hal-hal yang bersifat prinsipil guna melaksanakan syariat Islam.

3. Secara substansi yang ada dalam qanun mengatur mengenai akhlak. Tafsiran dari peneliti menunjukkan bahwa sasaran dari ruang lingkup akhlak adalah agar masyarakat Aceh secara umum hidup dangan tatanan nilai dan sosial yang harmonis.

Berkaitan pertanyaan peneliti kepada para guru yang berkaitan dengan integrasi maka pengintegrasian antara materi pada mata pelajaran Pendidikan Agama Islam dengan pokokpokok Syariat Islam dapat dilakukan yang memiliki keselarasan dengan materi ajar pada Pendidikan Agama Islam.

Pada proses pembelajaran peneliti melihat pada saat melakukan observasi bahwa materi-materi yang disampaikan oleh guru adalah materi-materi yang berkaitan dengan kedekatan manusia dengan Allah SWT serta berakhlak yang sesuai dengan suri tauladan Rasulullah SAW.

Penjelasan di atas menunjukkan bahwa mata pelajaran Pendidikan Agama Islam yang ada di sekolah khususnya sekolah yang menjadi objek penelitian sudah mendekati substansi dari materi yang ada pada Qanun Pokok-Pokok Syariat Islam.

Observasi peneliti seperti yang telah dijelaskan pada pembahasan sebelumnya bahwa guru juga menyampaikan mengenai pelaksanaan syariat Islam di Aceh, akan tetapi hal tersebut tidak mendalam, karena mata pelajaran Pendidikan Agama Islam memiliki materi tersendiri yang berasal dari pemeritahan pusat.

Materi pembahasan mengenai syariat Islam merupakan tanggung jawab moral bagi para guru, sekalipun hal ini tidak ada perintah khusus dari pemerintah Aceh apalagi dari materi ajar yang tersedia. Tanggung jawab moral ini semkain menjadi kuat karena ada faktor dari pelatihan yang diselenggarakan oleh Dinas Pendidikan Provinsi Aceh untuk pengajar mata pelajaran Pendidikan Agama Islam yang ada di Aceh.

Penelitan ini menunjukkan bahwa ada peluang yang dapat dilakukan guna mewujdukan integrasi materi pelajaran Pendidikan Agama Islam dengan pokok-pokok syariat Islam di Aceh, peluang tersebut adalah pada saat berlangsungnya proses pembelajaran di kelas. 
Hal ini dapat digambarkan dalam figura sederhana di bawah ini :

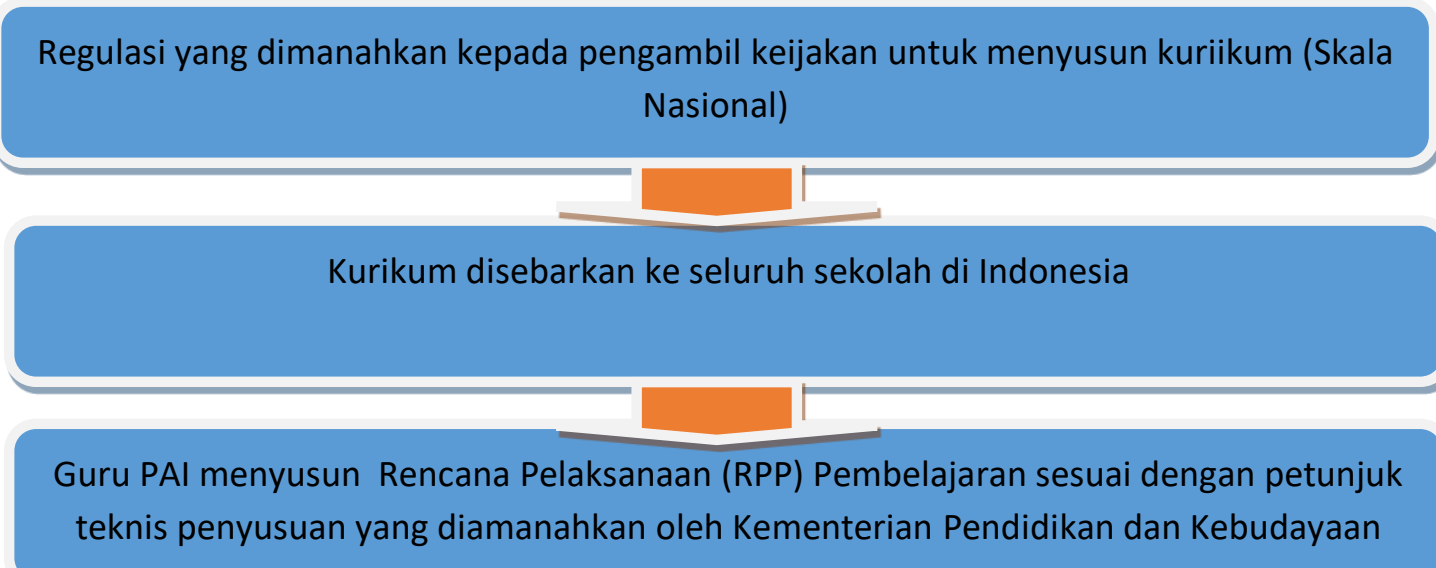

Gambar 3. Alur Sederhana Tentang Proses Pembelajaran

Skema di atas menggambarkan alur sederhana tentang proses akhir dari materi yang disampaikan oleh guru kepada siswa. Jika melihat alur di atas maka mengenai materi bahan ajar merupakan turunan dari kurikulum yang dibentuk oleh pengambil kebijakan di tingat pejabat, sementara turunannya ke bawah yakni pada tahapan penyusunan Rencana Pelaksanaan Pembelajaran (RPP) merupakan kewenangan guru.

Penelitian yang telah dilakukan serta ditambah dengan alur sederhana di atas menujukan bahwa ada peluang terbesar yang dapat di manfaatkan oleh pemerintah Aceh untuk melakukan integrasi antara Qanun pokok-pokok syariat Islam dalam pembelajaran yakni dengan memanfaatkan penyusunan Rencana Pelaksanaan Pembelajaran yang disusun oleh guru mata pelajaran Pendidikan Agama Islam.

Selain menjadi sebagai peluang, kesempatan tersebut juga menjadi upaya para guru Pendidikan Agama Islam untuk berinovasi dalam melakukan penyesuaian dengan kearifan yang telah di daerah.

Penjelasan di atas, selaras dengan apa yang peneliti lihat pada saat berlangsungnya proses pembelajaran di kelas. Observasi dilakukan pada saat berlangsungnya proses pembelajaran Pendidikan Agama Islam yang di ampu oleh Leni Marlina (2021). Materi yang disampaikan oleh Leni Marlina sesuai dengan kurikulum Pendidikan Agama Islam. Proses pembelajaran ini Leni Marlina mengawali dengan salam dan kemudian menyampaikan materi yang berkaitan dengan Aqidah serta materi mengenai Akhlak, dua materi ini memiliki keselarasan dengan cakupan yang ada dalam pokok-pokok syariat Islam. Selesai menyampaikan materi yang diajarkan Leni Marlina mengakhiri kembali dengan salam penutup.

Wawancara dengan Leni Marlina (2021) yang kemudian menjelaskan:

Pengalaman saya mengajar bahwa kelas merupakan tempat yang tepat dalam melakukan transfer pengetahuan kepada siswa dengan menjelaskan mengenai pelaksanaan syariat Islam, akan tetapi tidak semua materi dapat diajarkan, apalagi itu bukan materi yang harus disampaikan, sekali-kali materi tersebut menjadi contoh yang harus di sampaikan.

Pembelajaran merupakan hal terpenting dalam mengintegrasikan materi yang ada pada kurikulum Pendidikan Agama Islam dengan pokok-pokok syariat Islam. Proses pembelajaran ini merupakan titik temu proses transformasi pengetahuan yang ada pada guru kepada siswa, untuk itu keseriusan dalam melakukan inovasi, kreatifitas serta hal-hal baru berkaitan dengan materi ajar disampaikan pada saat proses pembelajaran. tidak semua bisa dijadikan bagian yang terintegrasi dengan pelaksanaan syariat Islam di Aceh. lebih lajut Leni Marlina memberikan contoh seperti materi Ahwal Al-Syakhshiyah, Mualamah, Jinayah, dan Qadha' sangat sulit untuk dijadikan bagian dari materi ajar kepada siswa, karena hal ini tidak dibahas pada tingkat siswa. 
Observasi untuk kedua kali dilaksanakan di kelas yang di ampu oleh Leni Marlina, observasi ini dilaksanakan 5 (lima) hari kemudian. Pada observasi ini Leni Marlina berusaha agar proses pembelajaran ini menarik untuk disimak oleh para siswa. Leni Marlina juga berusaha agar materi yang disampaikan dikelas diselaraskan dengan syariat Islam di Aceh.

Setelah selesai berlangsung proses pembelajaran peneliti berusaha menyempatkan waktu untuk wawancara, menurut Leni Marlina:

Bahwa upaya untuk menyelaraskan atau mengintegrasikan itu ada, hanya saja para guru tidak memiliki kewenangan untuk itu, barangkali yang dapat diselaraskan misalnya

Ibadah, Tarbiyah, Syiar dan Dakwah, karena hal ini juga ada hubugannya dengan materi ajar yang disebutkan dalam kurikulum.

Penjelasan guru di atas menunjukkan bahwasanya terdapat peluang besar yang dapat dilakukan untuk menyelaraskan antara materi yang telah ditentukan pemerintah mengenai materi pelajaran Pendidikan Agama Islam dengan materi-materi mengenai pokok-pokok syariat Islam yang ada di Aceh.

Pada bagian ini peluang untuk mengintegrasikan materi ajar Pendidikan Agama Islam bisa saja dilakukan dengan memanfaatkan proses pembelajaran di kelas tentunya dengan materi-materi yang telah di susun di RPP sebagai bahan ajar.

Setelah penjabaran penjelasan di atas, peneliti akan menjelaskan mengenai konsep yang akan menjadi tawaran dalam hasil penelitian ini.

Pertama adalah telaah dokumen yang dilakukan menunjukkan bahwa pada Salianan Lampiran Peraturan Menteri Pendidikan Dan Kebudayaan Nomor 37 Tahun 2018 Tentang Perubahan Atas Peraturan Menteri Pendidikan Dan Kebudayaan Nomor 24 Tahun 2016 Tentang Kompetensi Inti dan Kompetensi Dasar Pelajaran Pada Kurikulum 2013 Pada Pendidikan Dasar Dan Menengah menyebutkan beberapa yang serupa dengan apa yang disebutkan pada cakupan pokok syariat Islam. Telaah dokumen yang peneliti lakukan menemukan bahwa tidak semua hal yang diatur pada prinsip pokok syariat Islam itu ada dalam peraturan menteri tersebut.

Selanjutnya peneliti melakukan telaah dokumen pada turunan dari peraturan tersebut yaitu kurikulum masih menemukan hal yang sama dan kemudian peneliti melakukan telaah dokumen lanjutan hingga ke Rencana Pelaksanaa Pembelajaran (RPP). Pada tahapan ini peneliti melihat ada hal serupa tapi tidak sama dengan apa yang di atur dalam prinsip-prinsip qanun pokok syariat Islam.

Guna memastikan apa yang ditemukan pada telaah dokumen tersebut peneliti juga membandingkan dengan apa yang peneliti temukan pada saat observasi ketika berlangsungya proses pembelajaran. Data yang ditemukan ketika observasi adalah para guru menyampaikan mengenai prinsip-prinsip umum pelaksanaan syariat Islam, karena hal ini juga diatur dalam kurikulum di sekolah.

Data yang ditemukan di sekolah seperti yang telah dijelaskan pada bahagian sebelumnya menujukkan bahwa ada upaya yang dilakukan oleh para guru dalam menyampaikan materi syariat Islam di Aceh, hanya saja guru melaksanakan hal tersebut bukan karena perintah dari peraturan akan tetapi karena tanggung jawab moral yang muncul sebagai bagian dari semangat orang Aceh.

Data tersebut peneliti temukan pada saat wawancara dengan Zulmadewi :

Hal-hal yang berkaitan dengan pelaksanaan syariat Islam di Aceh pernah disampaikan kepada siswa pada saat berlangsungya proses pembelajaran di kelas. Zulmadewi melanjutkan penyampaian mengenai materi yang berkaitan dengan pelaksanaan syariat Islam didrorong oleh semangat ke-Acehan yang muncul, namun demikian materi ini tidak disebutkan secara detail di RPP.

Penjelasan dari Zulmadewi di atas menggambarkan semangat para guru untuk mendalami materi agama Islam melalui materi yang beragam yang tidak hanya bersumber dari kurikulum. Akan tetapi juga bersumber dari lingkungan sehari-hari. 
Disisi lain, Zulmadewi menjawab pertanyaan wawancara yang dilaksanakan bahwa semua materi yang diajarkan kepada peserta didik ketika berlangsungnya proses pembelajaran tetap berdasarkan pada kurikulum nasional.

Observasi yang peneliti lakukan berdasarkan pada dua belas (12) butir pertanyaan menunjukkan bahwa yang memiliki kaitan dengan prinsip-prinisp umum atau cakupan dari qanun pokok syariat Islam hanya sebanyak 6 (enam) bagian saja yaitu seperti yang disebutkan dalam table dibawah ini:

Tabel 1. Pengintegrasian oleh guru antara materi Qanun dengan Materi PAI ketika berlangsung pembelajaran di Kelas

\begin{tabular}{|c|l|c|}
\hline No & \multicolumn{1}{|c|}{ Materi Qanun } & \multicolumn{1}{|c|}{$\begin{array}{c}\text { Keintegrasian } \\
\text { Materi PAI }\end{array}$} \\
\hline 1 & Ibadah Ada \\
\hline 2 & Ahwal Al-Syakhsiyah & Tidak Ada \\
\hline 3 & Muamalah & Tidak Ada \\
\hline 4 & Jinayah & Tidak Ada \\
\hline 5 & Qadha & Tidak Ada \\
\hline 6 & Tarbiyah & Ada \\
\hline 7 & Pembelaan Islam & Tidak Ada \\
\hline 8 & $\begin{array}{l}\text { Setiap orang di Aceh wajib berperilaku dengan tuntunan } \\
\text { Islam }\end{array}$ & Ada \\
\hline 9 & $\begin{array}{l}\text { menghormati dan menegakkan nilai-nilai kemanusiaan, } \\
\text { persaudaraan, kasih sayang, kesetaraan, pernghormatan } \\
\text { sesama dan mencegah kerusakan }\end{array}$ & Ada \\
\hline 10 & Budaya pergaulan hidup dan tata busana yang Islami & Ada \\
\hline 11 & Bahaya dekadensi moral di era global & Tidak Ada \\
\hline 12 & $\begin{array}{l}\text { Islam tidak hanya mengatur akhlak dalam individu, tetapi } \\
\text { juga akhlak dalam badan hukum }\end{array}$ & \\
\hline
\end{tabular}

Dari penjelasan tabel di atas, menunjukkan bahwa keterkaitan antara materi qanun dengan materi pada saat proses pembelajaran di kelas berbanding 50:50. Observasi ini dilakukan ketika berlangsungnya proses pembelajaran di kelas.

Peneliti juga melakukan wawancara dengan Ida Irhami yang kemudian memberikan satu contoh, yaitu tentang materi Jinayah:

Materi Jinayah tidak disebutkan dalam kurikulum Pendidikan Agama Islam, akan tetapi materi Jinayah ini menjadi bahagian penting yang harus disampaikan kepada siswa. Hal ini disebabkan para siswa tinggal di Aceh dan bergaul di Aceh.

Materi mengenai jinayah apabila tidak disampaikan kepada peserta didik maka bisa jadi kedepananya akan menimbulkan persoalan baru. Materi Jinayah tersebut harus disampaikan dengan kreatifitas guru pada saat proses pembelajaran di kelas, dan memanfaatkan materi yang telah diatur dalam kurikulum pendidikan agama Islam.

Peneliti melakukan observasi pada saat berlangsungya proses pembelajaran. Ida Irhami dalam sela-sela berlangsungnya proses pembelajaran di kelas juga memberikan contoh tentang pelaksanaan syariat Islam, khususnya mengenai Jinayah. Ida Irhami memberikan penjelasan mengenai definisi Jinayah saja, hal ini disebabkan oleh karena materi pokok-pokok syariat Islam bukan bagian yang terstruktur dari kurikulum Pendidikan Agama Islam.

Observasi berikutnya terhadap proses pembelajaran yang dilakukan oleh Ida Irhami adalah dengan memantau materi yang disampaikan, materi-materi yang berkaitan memilki kesamaan antara kurikulum Pendidikan Agama Islam dengan Pokok-pokok Syariat Islam di Aceh. materi yang disampaikan oleh Ida Irhami yang memiliki kesamaan adalah seperti Akhlak, Ibadah serta Aqidah. 
Senada dengan Ida Irhami, terkait materi ajar pembelajaran pendidikan agama Islam sangat bersifat umum, hal ini dapat dilihat oleh peneliti pada saat berlangsungnya observasi lanjutan pada kelas yang diampu oleh Leni Marlina. Secara umum Leni Marlina menjelaskan mengenai menjaga keserasian hidup bermasyarakat, menjaga relasi yang baik dengan lingkungan, hal ini juga disebutkan dalam pokok-pokok syariat Islam. Pola yang sama juga peneliti lihat pada kelas Ida Irhami, bahwa transformai pengetahuan yang berlangsung sangat umum yang disetarakan dengan kelas yang diajarkan.

Berangkat dari data yang telah dipaparkan diatas, peneliti menemukan sebuah konsep yang dapat dimanfaatkan untuk melakukan konsep integrasi yaitu pada saat penyusunan Rencana Pelaksanaan Pembelajaran (RPP) yang disusun oleh guru yang digunakan untuk berlangsungnya proses pembelajaran dikelas. Konsep integrasi ini bisa dimanfaatkan untuk melakukan integrasi antara proses pembelajaran dengan pokok-pokok syariat Islam yang mana keduanya masih sama sama membahas nilai-nilai keIslaman, akan tetapi tidak semua cakupan yang ada pada pokok-pokok syariat Islam dapat diintegrasikan dengan pembelajaran di kelas.

\section{KESIMPULAN}

Berdasarkan pembahasandi atasdari penelitian yang telah dilakukan di Sekolah Menengah Atas Negeri 1 Tapaktuan Kabupaten Aceh Selatan dapat diambil kesimpulan sebagai berikut:

1. Integrasi qanun syariat Islam ke dalam pembelajaran Pendidikan Agama Islam menunjukkan bahwa di Sekolah Menengah Atas Negeri 1 Tapaktuan telah dilaksanakan pengintegrasian qanun syariat Islam ke dalam proses pembelajaran meskipun belum seluruhnya terintegrasi ke dalam pembelajaran, hal ini disebabkan karena materi qanun tersebut tidak menjadi bagian dari kurikulum Pendidikan Agama Islam pada Sekolah Menengah Atas. Namun sekolah tersebut tetap menyampaikan bagian dari qanun syariat Islam ke dalam pembelajaran PAI.

2. Proses pembelajaran mata pelajaran Pendidikan Agama Islam di SMAN 1 Tapaktuan yang telah dilakukan oleh para guru ketika proses pembelajaran berlangsung di kelas menunjukkan bahwa setiap guru yang mengajarkan mata pelajaran Pendidikan Agama Islam tetap menyampaikan materi-materi yang berkaitan dengan pokok-pokok syariat Islam di Aceh. Materi-materi yang di sampaikan tersebut masih terbatas pada yang berkaitan dengan kurikukum Pendidikan Agama Islam.

3. Konsep pengintegrasian antara Qanun Nomor 8 Tahun 2014 Tentang Pokok-Pokok Syariat Islam ke dalam pembelajaran pendidikan agama Islam di SMAN 1 Tapaktuan menemukan adanya peluang untuk melakukan pengintegrasian antara materi Pendidikan Agama Islam dengan prinsip-prinsip qanun pokok syariat Islam. Peluang tersebut ditemukan pada saat penyusunan Rencana Pelaksanaan Pembelajaran (RPP) oleh guru. Sesuai dengan data observasi, wawancara dan telaah dokumentasi di Sekolah Menengah Atas Negeri 1 Tapaktuan menunjukkan adanya peluang guna mewujudkan konsep integrasi tersebut.

\section{DAFTAR PUSTAKA}

Ali M. Luluk Y.R. (2004). Paradigma Pendidikan Universal Di Era Moderen Dan PostModeren.

Aprida pane, Muhammad Darwis Dasopang. (2017). Belajar dan Pembelajaran, Fitrah Jurnal Kajian Ilmu-Ilmu Keislaman, Vol.03 No.2 Desember 2017.

Askhobul Kiram. (2017). Peran Guru dan Peserta Didik Dalam Proses Pembelajaran Berbasis Multikultural. Al-Murabbi: Jurnal Pendidikan Agama Islam, Volume 3, Nomor 1

Ismail Raji Al-Faruqi. (1995). Islamisasi Pengetahuan, Terjemahan. Bandung: Pustaka.

Qanun Nomor 5 Tahun 2008 Tentang Penyelenggaran pendidikan, pasal 1 bab 1 ketentuan umum Pasal 1 nomor 37

Muhaimin. (2012). Pemikiran Dan Aktualisasi Pengembangan Pendidikan Islam. Jakarta: PT. Raja Grafindo Pesada. 
Oemar Hamalik. (2007). Kurikulum dan Pembelajaran. Jakarta : Bumi Aksara.

S. Nasution. (1995). Kurikulum dan Pengajaran. Bumi Aksara, Jakarta.

Sugihartono, dkk, (2007). Psikologi pendidikan. Yogyakarta, UNY Press.

Trianto. (2007). Model-model Pembelajaran Inovatif Berorientasi Konstruktivistik; Konsep, Landasan Teoritis-Praktis dan Implementasinya. Jakarta: Prestasi Pustaka Publisher.

Undang-Undang RI No. 20 Tahun 2003 tentang Sistem Pendidikan Nasional Bab I Pasal 1. Zainal Abiding Bagir. (2010). Integrasi IImu Dan Agama. Bandung: Mizan Pustaka. 